\title{
РОЛЬ І МІСЦЕ НАЦІОНАЛЬНОЇ АКАДЕМІЇ МЕДИЧНИХ НАУК УКРАЇНИ У НАДАННІ МЕДИЧНОЇ ДОПОМОГИ ВІЙСЬКОВОСЛУЖБОВЦЯМ ПІД ЧАС АТО/ООС
}

\author{
В.І. Цимбалюк ${ }^{1}$, I.A. Лурін ${ }^{1}$, В.О. Жаховський ${ }^{2}$, В.Г. Лівінський ${ }^{2}$, А.В. Швець ${ }^{2}$ \\ ${ }^{1}$ Національна академія медичних наук України, м. Київ, Україна \\ 2 Українська військово-медична академія, м. Київ, Україна
}

\begin{abstract}
Мета роботи - дослідження місия та ролі Національної академії медичних наук (НАМН) України та підпорядкованих їй науково-дослідних установ, в структурі яких є клінічні підрозділи, в системі надання медичної допомоги пораненим, ураженим, травмованим $i$ хворим військовослужбовиям під час антитерористичної операції та операції Об'єднаних сил (АТО/OоC).

Матеріали та методи. Використано нормативно-правові акти з питань національної безпеки держави та охорони здоров'я в Україні, публікації у відкритих наукових джерелах стосовно діяльності Національної академії медичних наук України в цілях надання медичної допомоги військовослужбовиям під час АTO/OOC. Методи дослідження - бібліографічний, статистичний, аналітичний, системного підходу.

Результати. НАМН України та підпорядковані їй науково-дослідні установи, в структурі яких $\epsilon$ клінічні підрозділи, під час АТО/ООС взяли активну участь у наданні медичної допомоги пораненим, ураженим, травмованим і хворим військовослужбовцям ЗС України та інших військових формувань. Робота НАМН України щодо надання медичної допомоги військовослужбовцям була багатовекторною і велася за декількома напрямами: організаційний, безпосереднього надання медичної допомоги та наукового супроводу. Клінічні установи НАМН України під час АТО/ООС не припиняли надання високоспеціалізованоі медичної допомоги цивільному населенню України, зокрема й вимушеним переселениям з районів проведення ATO/OOC.

Висновки. Завдяки злагодженій діяльності Президії НАМН України та підпорядкованих їй науководослідних установ зроблено вагомий внесок у надання високоспеціалізованої медичної допомоги пораненим, ураженим травмованим і хворим військовослужбовиям під час АТО/OОС, а також сформовано основні напрями розвитку вітчизняної військово-медичної науки: організаційний, лікувально-профілактичний та логістично-технологічний.
\end{abstract}

Ключові слова: охорона здоров'я, медична допомога, НАМН України.

Вступ. Тривалий збройний конфлікт на сході України призвів до чисельних безповоротних та санітарних втрат як військовослужбовців, так і цивільного населення України. За останніми даними управління Верховного комісара ООН з прав людини (УВКПЛ ООН) за весь період конфлікту, з 14 квітня 2014 року до середини 2020 року жертвами військового конфлікту стали понад 40 тисяч осіб [1]. За час війни загинуло близько 4100 українських військовослужбовців, понад 12 тисяч отримали поранення.

Під час антитерористичної операції та операції Об’єднаних сил (АТО/ООС) медичні служби Збройних Сил (3С) України та інших військових формувань вперше зустрілися 3 необхідністю медичного забезпечення військ в умовах бойових дій, надання медичної допомоги військовослужбовцям з бойовою хірургічною та терапевтичною патологією, а також з бойовою психічною травмою та 3 посттравматичними психічними розладами.

Військово-медичні служби власними силами здійснюють надання медичної допомоги пораненим, ураженим, травмованим та хворим військовослужбовцям безпосередньо на полі бою, на першому і другому рівнях медичного забезпечення та проводять медичну евакуацію. Водночас для надання спеціалізованої та високоспеціалізованої медичної допомоги військовослужбовцям через брак власних сил та засобів широко залучаються цивільні заклади охорони здоров'я, у тому числі й науково-дослідні державні установи (ДУ) Національної академії медичних наук (НАМН) України» $[2,3]$.

Порядок їх залучення визначений Розпорядженням Кабінету Міністрів України «Деякі питання медичного забезпечення військовослужбовців, осіб рядового і начальницького складу та поліцейських, які беруть участь в антитерористичній операції та здійсненні заходів із забезпечення національної безпеки і оборони, відсічі і стримування збройної агресії Російської Федерації у Донецькій та Луганській областях» та спільним наказом Міністерства оборони України та Міністерства охорони здоров'я України «Про визначення механізму надання вторинної (спеціалізованої) i 
третинної (високоспеціалізованої) медичної допомоги військовослужбовцям, які беруть участь в антитерористичній операції та здійсненні заходів із забезпечення національної безпеки і оборони, відсічі і стримування збройної агресії Російської Федерації та/або в умовах запровадження воєнного чи надзвичайного стану» $[4,5]$.

Згідно цих нормативних актів для надання високоспеціалізованої медичної допомоги військовослужбовцям - учасникам бойових дій, а також лікування поранених, уражених, травмованих і хворих військовослужбовців НАМН України виділяє 1001 госпітальне ліжко у 27 підпорядкованих клінічних установах, у тому числі 601 ліжко хірургічного профілю та 400 ліжок терапевтичного профілю.

Порядок організації співпраці НАМН України з органами управління медичним забезпеченням 3С України щодо надання медичної допомоги військовослужбовцям детально визначено у «Методичних рекомендаціях з організації роботи цивільних закладів охорони здоров'я щодо надання вторинної (спеціалізованої) та третинної (високоспеціалізованої) медичної допомоги військовослужбовцям Збройних Сил України та інших військових формувань» [6].

Від самого початку АТО на сході України та під час ООС клінічні установи НАМН України на засадах єдиного медичного простору України, які детально розкриті в монографії «Єдиний медичний простір та військова медицина», взяли активну участь у наданні медичної допомоги пораненим, ураженим, травмованим і хворим військовослужбовцям 3С України та інших військових формувань [7]. Крім того, увесь цей час клінічні установи НАМН України не припиняли надання високоспеціалізованої медичної допомоги населенню України, зокрема й вимушеним переселенцям 3 районів проведення АТО/ООС.

Мета роботи полягає в дослідженні місця та ролі НАМН України та підпорядкованих їй науково-дослідних установ, в структурі яких $\epsilon$ клінічні підрозділи, в системі надання медичної допомоги пораненим, ураженим, травмованим і хворим військовослужбовцям під час АТО/ООС.

Матеріали та методи. В якості матеріалів дослідження використано нормативно-правові акти з питань національної безпеки держави та охорони здоров'я в Україні, публікації у відкритих наукових джерелах стосовно діяльності Національної академії медичних наук України в цілях надання медичної допомоги військовослужбовцям під час АТО/ООС. Методи дослідження: бібліо-семантичний, історичний, статистичний, аналітичний, системного підходу.

Результати дослідження та їх обговорення. Робота НАМН України щодо надання медичної допомоги пораненим, ураженим, травмованим i хворим військовослужбовцям ЗС України та інших утворених відповідно до законів військових формувань та правоохоронних органів, особам рядового i начальницького складу та поліцейським, які беруть участь в АТО/ООС та здійсненні заходів із забезпечення національної безпеки і оборони, відсічі і стримування збройної агресії Російської Федерації у Донецькій та Луганській областях, була багатовекторною та велася за такими основними напрямами:

участь Президії НАМН України в організаційно-методичному керівництві організацією надання медичної допомоги пораненим, ураженим, травмованим і хворим військовослужбовцям;

надання високотехнологічної високоспеціалізованої медичної допомоги найбільш тяжким пораненим, ураженим, травмованим i хворим військовослужбовцям, потребуючим довготривалого та складного лікування, фахівцями клінічних установ НАМН України, які безпосередньо залучені до системи лікувальноевакуаційних заходів медичного забезпечення військ;

збір, аналіз та узагальнення набутого досвіду медичного забезпечення військ під час бойових дій в районах проведення АТО/ООС, а також пошук і наукове обгрунтування сучасних підходів до діагностики та розроблення нових методик надання медичної допомоги пораненим, ураженим, травмованим і хворим військовослужбовцям - учасникам бойових дій.

3 початком АТО на сході України для надання третинної (високоспеціалізованої) медичної допомоги військовослужбовцям - учасникам бойових дій були задіяні майже всі наукові установ НАМН України, в структурі яких $€$ клінічні підрозділи. Їхня робота була організована i проводилася відповідно до законодавства України про охорону здоров'я та Статуту Національної академії медичних наук України $[8,9]$.

3 метою забезпечення готовності наукових установ НАМН України до надання медичної допомоги жертвам війни та належної організації їх роботи на виконання Рішення Комітету Верховної Ради України з питань охорони здоров’я «Про вжиття невідкладних заходів для поліпшення стану організації медичного забезпечення населення та учасників 
антитерористичної операції» та Указу Президента України «Про невідкладні заходи із забезпечення державної безпеки» $[10,11]$ був виданий наказ НАМН України «Про невідкладні заходи щодо надання медичної допомоги установами НАМН України» [12].

Також на виконання наказу Міністерства охорони здоров’я (МО3) України «Про додаткові заходи щодо забезпечення функціонування закладів охорони здоров'я в умовах особливого періоду та подолання наслідків надзвичайної ситуації державного рівня соціального та воєнного характеру» [13] Президією НАМН України була видана низка наказів, які регламентують діяльність підпорядкованих наукових установ в особливий період. На виконання цих наказів в НАМН України:

створено оперативний штаб 3 надання допомоги пораненим в зоні АТО;

сформовано мобільні бригади, що перебувають у готовності до виїзду на допомогу пораненим із закріпленими за ними транспортними засобами, укомплектованими медичним обладнанням, виробами медичного призначення та лікарськими засобами;

розроблено графіки чергувань мобільних бригад та затверджено схеми цілодобового оповіщення;

сформовано резерв лікарів-волонтерів, готових виїхати в зону АТО для підсилення медичних закладів II-го рівня (більше 77 хірургів, травматологів, анестезіологів);

укладено угоди про співпрацю щодо надання високоспеціалізованої високотехнологічної медичної допомоги військовослужбовцям між НАМН України та Військово-медичним департаментом МО України, Службою безпеки України, Управлінням медичного забезпечення та реабілітації Міністерства внутрішніх справ України, Національним військово-медичним клінічним центром «ГВКГ» МО України, Центральним клінічним госпіталем Державної прикордонної служби України, Центральним госпіталем Військово-медичного управління СБ України, Центральним клінічним госпіталем ДПС України та Центральним госпіталем МВС України.

У серпні 2014 року за ініціативи та безпосередньо під керівництвом президента НАМН України разом зі співробітниками Науково-дослідного інституту проблем військової медицини Української військовомедичної академії та Військово-медичного департаменту Міністерства оборони України була розпочата робота щодо опрацювання Воєнно-медичної доктрини України (Доктрина), яка затверджена відповідною постановою Кабінету Міністрів України» [14]. Доктрина визначає, що наукове супроводження розвитку системи охорони здоров'я військовослужбовців та розв'язання проблем військової медицини здійснює Національна академія медичних наук спільно з МО України та МОЗ України, які:

організовують та спрямовують діяльність науково-дослідних установ на розв'язання проблем військової медицини;

забезпечують розроблення і впровадження сучасних медичних технологій надання медичної допомоги, проведення лікування та реабілітації військовослужбовців і цивільного населення в разі поранень, травм та захворювань як у польових, так і у стаціонарних умовах;

здійснюють науковий супровід розробок вітчизняних медичних i технічних виробів, лікарських засобів для потреб ЗС України та інших військових формувань.

Спільним наказом Міністерства оборони України, Міністерства охорони здоров'я України, Міністерства внутрішніх справ України, Служби безпеки України та Національної академії медичних наук України від 13.05.2015 № 207/272/556/311/34 «Про створення Військово-цивільного координаційного штабу медичної допомоги» віце-президент Національної академії медичних наук України введений до складу Військово-цивільного координаційного штабу медичної допомоги, основним призначенням якого $€$ координація дій, спрямованих на забезпечення надання медичної допомоги військовослужбовцям 3С України, інших військових формувань, правоохоронних органів і цивільному населенню під час проведення антитерористичної операції.

3 метою упорядкування роботи НАМН України 3 питань надання медичної допомоги пораненим, ураженим травмованим i хворим військовослужбовцям, а також внутрішньо переміщеним особам під час АТО в складі лікувально-організаційного управління НАМН України було створено відділ з мобілізації та організації надання медичної допомоги постраждалим в зоні ATO, який в подальшому реорганізовано в сектор організації надання медичної допомоги постраждалим у зоні АТО. Його основними завданнями $\epsilon$ організація надання високоспеціалізованої медичної допомоги військовослужбовцям і громадянам України, які постраждали в районах проведення АTO, здійснення контролю за створенням i впровадженням наукових розробок, методичних рекомендацій, інформаційних листів, друкованих наукових робіт 3 питань надання 
високоспеціалізованої медичної допомоги постраждалим в ATO, а також координація взаємодії та поєднання зусиль фахівців наукових установ НАМН України з медичними службами військових формувань для ефективного i своєчасного надання високоспеціалізованої медичної допомоги.

Розуміючи загальнодержавну актуальність наукових досліджень в інтересах медичного забезпечення 3С України та інших військових формувань у 2017 році в системі медичної науки України окремо виділений військово-медичний науковий напрямок та проведені вибори до складу НАМН України за спеціальностями «Науково-медичне забезпечення Збройних Сил та правоохоронних органів» і «Військова хірургія».

Продовження науково-практичної роботи у цьому важливому напрямку, пов язаному 3 медичним забезпеченням 3С України та інших військових формувань, наданні медичної допомоги пораненим, травмованим і хворим військовослужбовцям і цивільному населенню в умовах АТО/ООС призвело до необхідності створення профільного наукового підрозділу у НАМН України. Відповідною постановою Президії НАМН України № 8/3 від 22 листопада 2018 року створено відділ військово-медичної науки при Президії НАМН України, який очолив доктор медичних наук, професор, членкореспондент НАМН України, керівник департаменту 3 питань охорони здоров'я Адміністрації Президента України, генералмайор медичної служби Ігор Лурін. 3 метою створення умов для організації та координації провадження спільної наукової діяльності та виконання сумісних наукових проєктів, пов'язаних з науковим узагальненням досвіду військово-медичної науки та практики при проведенні АTO/OOC i направлених на підвищення національної безпеки та обороноздатності держави, головним науковим консультантом цієї роботи став доктор медичних наук, професор, член-кореспондент НАМН України, генерал-майор медичної служби Ігор Хоменко.

3 метою підтримання на належному рівні боєздатності 3С України та інших військових формувань, а також підвищення ефективності медичного забезпечення Сил оборони в умовах бойових дій науково-дослідні установи НАМН України беруть участь у наукових дослідженнях, головним виконавцем яких $є$ Українська ВМА, а саме:

«Розвиток системи медичного забезпечення за досвідом здійснення заходів із забезпечення національної безпеки і оборони, відсічі i стримування збройної агресії Російської Федерації», шифр «Простір» (науковий керівник: академік НАМН України, член-кореспондент НАН України, д-р мед. наук, проф. Цимбалюк В.I.);

«Обгрунтування норм фізіологічних потреб в основних харчових речовинах та енергії для військовослужбовців Сил спеціальних операцій Збройних Сил України», (науковий керівник: д-р мед. наук, проф. Гуліч М.П.);

«Фізіолого-гігієнічне обгрунтування нутрієнтного складу добового раціону харчування військовослужбовців Сил спеціальних операцій», (науковий керівник: д-р мед. наук, проф. Гуліч М.П.).

Творча робота у рамках спільної науководослідної роботи Української ВМА та НАМН України за шифром «Простір» триває і далі.

Так, за проміжними результатами проведення цієї роботи 3 вивчення та узагальнення досвіду надання медичної допомоги пораненим, ураженим, травмованим і хворим військовослужбовцям, а також цивільному населенню, яке стало жертвами війни на Сході України, за участі науководослідних установ НАМН України опрацьовано та видано унікальні видання, що присвячені військовим медикам України, які виконали свій обов'язок:

«Акушерсько-гінекологічна допомога та збереження репродуктивного здоров'я у жінок в умовах збройного конфлікту». Монографія окреслює основні шляхи вирішення наявних проблем акушерсько-гінекологічної допомоги та збереження репродуктивного здоров'я ужінок, що проходять військову службу та з числа внутрішньо переміщених осіб, в умовах збройного конфлікту. у ній висвітлено особливості захворюваності серед жінок військовослужбовців, становлення та інволюцію репродуктивної функції ж жінокз огляду на стресасоиійований характер розладів репродуктивного здоров'я, підходи до їх профілактики з врахуванням комплексного впливу факторів воєнного середовища ще на етапі підготовки жінок до військової служби. В роботі висвітлено особливості клініки, діагностики та лікування ушкоджень жіночих статевих органів при бойовій хірургічній травмі на різних рівнях медичного забезпечення.

«Бойова травма серця, грудної аорти та магістральних судин кінцівок». $B$ роботі узагальнено досвід Національного інституту серцево-судинної хірургії імені М.М. Амосова, кардіохірургів Інституту загальної та невідкладної хірургї імені В.Т. Зайцева, та 
військових госпіталів. Монографія містить дуже багато інформації, яка потрібна практикуючим хірургам, майбутнім лікарям.

Уперше у вітчизняній науковій літературі узагальнено історію діагностики та лікування бойової травми серия, описано основні патофізіологічні синдроми, що супроводжують поранення серия та магістральних судин, у тому числі геморагічний шок, анестезіологічна та реаніматологічна допомога, травматичний шок тощо, викладено оригінальні алгоритми та схеми надання допомоги пораненим.

«Досвід організації санітарно-гігієнічного та протиепідемічного забезпечення військ (сил) під час проведення антитерористичної операції (операції Об'єднаних сил)». Монографбія розроблена з метою удосконалення важливої складової медичного забезпечення військ (сил) забезпечення санітарно-епідеміологічного благополуччя. Особливу увагу приділено вивченню основних принципів санітарно-гігієнічного та протиепідемічного забезпечення армій країнчленів НАТО. Висвітлені питання епідеміологічних особливостей інфекційноі патології військовослужбовців, наведені особливості організації водопостачання, харчування, розміщення, лазне-прального обслуговування військовослужббовців під час проведення АТО (ООС). Окремо висвітлено питання біологічної безпеки та екологічних наслідків гібридної війни на Сході України. Наведені матеріали наукових досліджень, що виконані в тісній співпраці з фахівиями ДУ «Інститут громадського здоров'я ім. О.М. Марзєєва НАМН України».

«Лікування поранених з бойовими травмами кінцівок (за досвідом АТО/ООС)». Виходячи $з$ досвіду проведення АТО/ООС на сході України, науково обгрунтовано, розроблено і впроваджено організаційні засади надання травматологічної допомоги військовослужбовиям 3 бойовими травмами кінцівок на рівнях медичного забезпечення, центральним елементом якої $\epsilon$ саме організація надання травматологічної допомоги, що базується на сукупності нових діагностичних, лікувальних, профілактичних та реабілітаційних заходів та управлінських рішень. В монограбії запропонована сучасна класифікація бойової травми кінцівок. Висвітлені питання механогенезу та особливостей ушкоджуючої дії висококінетичних та мінно-вибухових снарядів Запропоновані сучасні методи тимчасової зупинки зовнішньої кровотечі, особливості проведення транспортної іммобілізації, первинної хірургічної обробки рани, тактики «Damage Control Surgery», надання спеціалізованої допомоги при компартмент-синдромі, використання сучасних методик механотрансдукції при хірургічних обробках вогнепальних ран, видалення осколків за допомогою неодимових магнітів та під контролем ультразвукової діагностики. Вперше розроблена методика накладання стержневого апарата зовнішньої фіксації на другому рівні медичного забезпечення. Обгрунтовані принципи повторної хірургічної обробки вогнепальних ран «second look» на третьому рівні медичного забезпечення. На рівні високоспеціалізованої допомоги дістала подальшого розвитку хірургічна технологія заміни методу фіксації при лікуванні поранених з вогнепальними переломами довгих кісток, хірургічна тактика при вогнепальних поліструктурних пошкодьженнях кінцівок 3 урахуванням інфекційних ускладнень. Тактика лікування поранених з ампутацією внаслідок бойової травми тощо.

«Патоморфоз вогнепальних ран м'яких тканин». Основу роботи склав колективний труд військових та цивільних медиків НАМН України, що базується на вивченні ранового процесу вогнепальних поранень м'яких тканин у поранених, які проходили лікування на базі хірургічних клінік МО та НАМН Украӥни (ДУ «Інститут загальної та невідкладної хірургії імені В.Т. Зайцева НАМН України»). Виявлені патоморфологічні зміни м'яких тканин при сучасних вогнепальних пораненнях у прощесі хірургічних обробок, місцевого лікування, що базувалися на власному досвіді участі в бойових діях під час надання хірургічної допомоги військовослужбовцям. Виявлені макроскопічні та мікроскопічні особливості динаміки ранового процесу (репарації та регенерації в м'яких тканинах). Завдяки опублікованим рекомендаціям фахівців вдасться уникнути помилок у діагностиці та лікуванні вогнепальних ран. Адже вивчення патоморфологічної картини кожної фази ранового процесу дозволяє оцінити й порівняти ефективність сучасних методів лікування, розробити і впровадити найбільш оптимальні технології.

«Розвиток системи фізичної та реабілітаційної медицини в умовах ведення збройного конфлікту». Висвітлено основні здобутки наукового супроводу становлення системи медичної реабілітації в ЗС України, роз'яснено порядок застосування основних та деяких допоміжних методів відновного лікування та діагностики порушення функціонування, обмежень життєдіяльності та здоров'я військовослужбовців на різних рівнях медичного забезпечення в ЗС України. Враховано вимоги 
національних уніфікованих клінічних протоколів медичної допомоги, керівництв та рекомендацій ВООЗ, а також досвід країн НАТО (США та Великобританії) в організації реабілітаційного процесу. Ця сумісна праця стала корисною у практичній роботі лікарів та інших фахівців госпітальної, санаторно-курортної та амбулаторно-поліклінічної ланки медичної служби ЗС України, які задіяні в реабілітаційному процесі.

«Стрес-асоційовані розлади здоров'я в умовах збройного конфлікту». В роботі спільно з Національним науковим центром «Інститут кардіології імені академіка М.Д. Стражеска» на основі комплексного медико-соціального дослідження було науково обгрунтовано шляхи оптимізації реабілітаційних заходів при стресасоційованих розладах здоров'я в умовах збройного конфлікту для продовження середньої тривалості та якості життя військовослужбовців - учасників бойових дій, цивільного населення в районах проведення ATO/OOC, а також внутрішньо переміщених осіб з тимчасово окупованих територій. За допомогою отриманих результатів наукового дослідження, розроблено методики відновлення психологічного та соціального статусу учасників збройного конфлікту, описані алгоритми $і$ шкали прогнозування ефективності реабілітаційних заходів. Книга стала корисною для лікарів різних спеціальностей, психологів, соціальних працівників тощо.

«Вогнепальні поранення м`яких тканин. Досвід АТО/ООС». B роботі висвітлені оптимальні диференційовані підходи до хірургічного лікування вогнепальних поранень м'яких тканин $з$ урахуванням обсягу їх пошкодження, анатомо-функціональної зони ураження, видуі характеру поранення, визначення зони життєздатних тканин. Детально висвітлені методики видалення сторонніх тіл з м'яких тканин та пластичного закриття ран, доведено ефективність застосування розробленого магнітного багатофункціонального інструментарію для діагностики і видалення металевих феромагнітних сторонніх тіл. рамках цієї тематики використовувались різні інструментальні методики (рентгеноструктурний та рентгеноспектральний аналіз на базі лабораторії рентгеноспектрального аналізу кафедри фізики металів та напівпровідників Національного технічного університету «ХПІ». Світлова мікроскопія проводилася на базі лабораторії ДУ «Інститут медичної радіологї̈ НАМН України ім. С.П. Григор'єва». Забір матеріалу, опис та аналіз препаратів проводили на базі лабораторії патоморфології та експериментальної хірургії ДУ «Інститут загальної та невідкладної хірургії НАМН України ім. В.T. Зайцева». Різнопланова науково-практична допомога постійно надавалась з боку ДУ «Національний інститут хірургії та трансплантології НАМН України ім. о.о. Шалімова».

Готується до видання навчальний посібник «Вогнепальні непроникаючі черепно-мозкові поранення». Триває робота над іншими.

Слід окремо наголосити на тому, що результати спільної наукової діяльності військових медиків та співробітників НАМН України були визнані на державному рівні, про що свідчать отримання авторськими колективами наступних державних премій:

за роботу «Новітні технології діагностики i лікування бойової вогнепальної травми та ії наслідків» присуджено державну премію України в галузі науки i техніки 2018 року (Указ Президента України №110/2019 від 08.04.2019);

за роботу «Стрес-асоційовані розлади здоров'я в умовах збройного конфлікту» присуджено державну премію України в галузі науки і техніки 2018 року (Указ Президента України №112/2019 від 08.04.2019);

за роботу «Високотехнологічні методи надання спеціалізованої стоматологічної допомоги в мирний та воєнний час» присуджено державну премію України в галузі науки і техніки 2019 року (Указ Президента України №4/2029);

за роботу «Реформування військовомедичної освіти України: теоретикометодологічне обгрунтування i практичне впровадження системи підготовки медичних фахівців для сил оборони та медицини катастроф» присуджено Державну премію України в галузі освіти 2018 року (Указ Президента України №301/2018);

за роботу «Інноваційний підхід з організації та надання медичної допомоги у гібридній війні» присуджено премію Кабінету Міністрів України за розроблення і впровадження інноваційних технологій (Розпорядження Кабінету Міністрів України від 6 квітня 2016 р. № 278-р).

Реалізуючи засади організаційнометодичного керівництва організації надання медичної допомоги пораненим, травмованим і хворим військовослужбовцям, а також іншим категоріям осіб, які постраждали внаслідок бойових дій під час АТО/ООС, науковцями НАМН України підготовлено 18 методичних рекомендацій та 11 інформаційних листів, які відображають особливості надання медичної 
допомоги (діагностики, лікування та методів реабілітації) постраждалим в умовах бойових дій.

Для забезпечення належного рівня медичної допомоги, підвищення рівня теоретичних знань та практичних навичок лікарів, які працюють в районах проведення АТО/ООС, відповідно до профілю наукових установ НАМН України (переважно хірургічного) розроблені тематичні плани лекцій та тематика відповідних тренінгкурсів для навчання та по удосконаленню знань і навичок з військово-польової хірургії.

3 метою уніфікації та стандартизації підходів щодо організації та надання медичної допомоги учасникам АТО установами НАМН України під керівництвом та за участі фахівців Сектору організації надання медичної допомоги постраждалим у зоні АТО розроблено «Дорожню карту надання медичної допомоги учасникам АTO в наукових установах НАMН України» (Дорожня карта). Програма Дорожньої карти передбачає організацію медичного забезпечення амбулаторно-консультативного, стаціонарного, реабілітаційного, психологічного, відновного лікування та інших видів високоспеціалізованої медичної допомоги військовослужбовцям та працівникам 3С України та інших військових формувань, які беруть участь в АТО/ООС.

За результатами проведення наукових i науково-дослідних робіт, вивчення та узагальнення досвіду надання медичної допомоги пораненим, ураженим, травмованим і хворим військовослужбовцям, а також цивільному населенню, яке стало жертвами війни на сході України, науково-дослідними установами НАМН України опрацьовано та видано 13 монографій, 6 посібників, 2 довідника та одні клінічні рекомендації.

Одним із важливих напрямів організаційнометодичного керівництва організацією надання медичної допомоги пораненим, травмованим і хворим військовослужбовцям, а також іншим категоріям осіб, які постраждали внаслідок бойових дій під час АТО/ООС, $є$ проведення щорічних науково-практичних конференцій, що присвячені впровадженню наукових розробок НАМН України щодо особливостей надання медичної допомоги учасникам АТО/ООС i цивільному населенню, яке зазнало уражень внаслідок бойових дій на сході України. За результатами вивчення та узагальнення досвіду надання медичної допомоги пораненим, ураженим, травмованим i хворим військовослужбовцям та цивільному населенню, а також 3 метою його поширення та запровадження у широку практику охорони здоров'я в Україні та на міжнародному рівні, за ініціативи, під керівництвом та за участю Президії НАМН України організовано та проведено 9 науково-практичних конференцій. Також у рамках Міжнародного медичного форуму НАМН України була організатором та провела шість науково-практичних конференцій, присвячених питанням впровадження наукових розробок наукових установ НАМН України та особливостям надання медичної допомоги військовослужбовцям - учасникам АТО/ООС i цивільному населенню, яке постраждало внаслідок бойових дій. Загалом у цих науковопрактичних конференціях взяло участь близько чотирьохсот лікарів різних спеціальностей.

Крім того, в період 2014-2019 років НАМН України брала участь у законотворчій діяльності, зокрема в опрацюванні проєктів постанов i розпоряджень Кабінету Міністрів України, нормативних актів МО України та МО3 України, за результатами чого погоджувала або надавала пропозиції / зауваження до вищезазначених документів, які враховувались авторами проєктів.

На виконання наказу Міністерства охорони здоров’я України «Про додаткові заходи щодо забезпечення функціонування закладів охорони здоров'я в умовах особливого періоду та подолання наслідків надзвичайної ситуації державного рівня соціального та воєнного характеру» [13] та відповідно до постанов та наказів Президії НАМН України, в клініках 24 наукових установ НАМН України у містах Київ, Львів, Одеса та Харків зарезервовано від 10-ти до 30-ти відсотків ліжкового фонду для поранених, уражених, травмованих та хворих, що разом складає 550 ліжок. Загалом же у клінічних установах НАМН України розгорнуто та функціонує 4026 ліжок хірургічного профілю.

У цих клінічних наукових установах створені спеціалізовані бригади для надання невідкладної медичної допомоги постраждалим як безпосередньо в закладах, так і для виїздів за їх межі, організовано цілодобове чергування висококваліфікованих фахівців та цілодобовий прийом постраждалих, які потребують невідкладної медичної допомоги. У деяких клінічних наукових установах НАМН України створені спеціалізовані центри та відділення бойової травми для надання високоспеціалізованої медичної допомоги учасникам ATO/OOC. Крім того, створено необхідний запас медикаментів, наборів медичних інструментів, препаратів крові та кровозамінників, лікарських засобів для протишокової терапії, стерильних розчинів, шовного та перев'язувальних матеріалів, 
контрастних речовин та інших засобів медичного призначення. Станом на початок 2020 року в клініках наукових установ НАМН України проконсультовано 16680 військовослужбовців учасників бойових дій, з них госпіталізовано 4326 осіб (табл. 1).

Показники роботи клінічних установ НАМН України щодо надання медичної допомоги військовослужбовцям - учасникам АТО/ООС

\begin{tabular}{|c|c|c|c|c|c|c|}
\hline \multirow[t]{2}{*}{ Роки } & \multicolumn{2}{|c|}{$\begin{array}{c}\text { Проконсультовано } \\
\text { військовослужбовців - } \\
\text { учасників АТО/ООС }\end{array}$} & \multicolumn{2}{|c|}{$\begin{array}{c}\text { Госпіталізовано } \\
\text { військовослужбовців - } \\
\text { учасників АТО/ООС }\end{array}$} & \multicolumn{2}{|c|}{$\begin{array}{c}\text { Надано консультативно- } \\
\text { лікувальну допомогу } \\
\text { в інших } 303\end{array}$} \\
\hline & $\begin{array}{c}\text { Показник } \\
\text { за рік }\end{array}$ & $\begin{array}{c}3 \text { початку } \\
\text { АТо }\end{array}$ & $\begin{array}{c}\text { Показник } \\
\text { за рік }\end{array}$ & $\begin{array}{c}3 \text { початку } \\
\text { АТо }\end{array}$ & $\begin{array}{c}\text { Показник } \\
\text { за рік }\end{array}$ & $\begin{array}{c}3 \text { початку } \\
\text { АТО }\end{array}$ \\
\hline 2015 & 974 & 974 & 608 & 608 & 765 & 765 \\
\hline 2016 & 5002 & 5976 & 1654 & 2262 & 406 & 1171 \\
\hline 2017 & 3507 & 9483 & 587 & 2849 & 16 & 1187 \\
\hline 2018 & 2673 & 12156 & 557 & 3406 & 29 & 1216 \\
\hline 2019 & 3554 & 15710 & 736 & 4142 & 8 & 1224 \\
\hline $\begin{array}{ll}\text { станом } & \text { на } \\
01.05 .2020 & \end{array}$ & 970 & 16680 & 184 & 4326 & - & 1224 \\
\hline
\end{tabular}

Найбільшу кількість поранених, уражених, травмованих і хворих військовослужбовців учасників АТО/ООС проконсультовано та проліковано стаціонарно в установах НАMН України у 2016 році (проконсультовано 5002 пацієнти, стаціонарно проліковано 1654 пацієнти).

Серед клінічних наукових установ НАМН України найбільшу кількість поранених, уражених, травмованих i хворих військовослужбовців - учасників АТО/ООС було проконсультовано в ДУ «Інститут нейрохірургії імені академіка А.П. Ромоданова» (3 779 осіб), ДУ «Інститут травматології та ортопедії» (2596 осіб) та ДУ «Інститут отоларингології імені професора 0.С. Коломійченка» (2087 осіб).

Відповідно до укладених угод про співпрацю між НАМН України та Національним військовомедичним клінічним центром «ГВКГ» МО України, Центральним госпіталем Військовомедичного управління СБ України, Центральним клінічним госпіталем ДПС України, Центральним госпіталем МBC України фахівцями наукових установ НАМН України здійснювалися виїзди до зазначених закладів охорони здоров'я та інших військово-медичних закладів, у тому числі наближених до районів бойових дій, для надання консультативної та високоспеціалізованої високотехнологічної медичної допомоги пораненим військовослужбовцям, в яких загалом було проконсультовано 1224 особи.

За наявності медичних показань пацієнти, які потребували високоспеціалізованої медичної допомоги, направлялися на госпіталізацію до профільних наукових установ НАМН України. Найбільше поранених, уражених, травмованих і хворих військовослужбовців - учасників
ATO/OOC проліковано стаціонарно у ДУ «Інститут травматології та ортопедії» (1091 особа), ДУ «Інститут медицини праці імені Ю.І. Кундієва» (846 осіб), ДУ »Гнститут нейрохірургії імені академіка А.П. Ромоданова» (657 осіб), ДУ «Інститут отоларингології імені професора О.С. Коломійченка» (447 осіб), ДУ «Національний інститут хірургії і трансплантології імені 0.0. Шалімова» (165 осіб).

За час проведення АТО/ООС в поліклінічних відділеннях клінічних наукових установ НАМН України поряд з військовослужбовцями учасниками бойових дій було проконсультовано та надано медичну допомогу 176611 цивільним пацієнтам з Донецької та Луганської областей, а в умовах стаціонару проліковано 58872 особи.

Збройний конфлікт та тривалі бойові дії на сході України виявили ще одну загальнодержавну проблему охорони здоров'я, а саме - нагальну потребу в медичній, медикопсихологічній та соціальній реабілітації військовослужбовців - учасників бойових дій та інших жертв війни. Наявність проблем у цій сфері реабілітаційної медицини було офіційно підтверджено в грудні 2015 року Оцінювальною місією ВООЗ та Міжнародним товариством фізичної та реабілітаційної медицини.

3 метою їх вирішення фахівцями наукових установ НАМН України опрацьовано методики діагностики та комплексного лікування 3 використанням медикаментозного лікування, психотерапії та фізіотерапевтичних процедур. У співпраці фахівців Української військовомедичної академії (УВМА) та Національного наукового центру «Інститут кардіології імені академіка М.Д. Стражеска» були закладені основи медико-психологічної реабілітації в нашій 
державі, що знайшло відображення в колективній монографії «Стрес-асоційовані розлади здоров'я в умовах збройного конфлікту».

32018 року розпочато міжгалузевий проект, який базується на поєднанні зусиль НАМН України, УВМА та закладів охорони здоров'я М03 України щодо фундаментальних досліджень проблеми контузії та її наслідків.

На базі клініки професійних захворювань ДУ «Інститут медицини праці імені Ю.І. Кундієва» у листопаді 2014 року створено відділення медико-психологічної та психо-фізіологічної реабілітації учасників АТО на 40 ліжок, в якому проліковано понад 850 пацієнтів. До складу відділення введено 2 посади психотерапевта та одну посаду медичного психолога.

Також для надання кваліфікованої медикопсихологічної допомоги пацієнтам було укладено Угоду про співпрацю між ДУ «Інститут медицини праці імені Ю.І. Кундієва» НАМН України та ДУ «Інститут психологї імені Г.С. Костюка» Національної академії педагогічних наук України, згідно якої до реабілітаційного процесу долучено 20 висококваліфікованих сертифікованих спеціалістів психологів на волонтерських засадах, які мають наукові ступені та досвід роботи 3 військовою психотравмою із застосуванням сучасних психотерапевтичних методів.

В ДУ «Інститут неврології, психіатрії та наркології» з 2014 року працює «Реабілітаційний центр для учасників АТО» як координаційнофункціональний підрозділ, що забезпечує оптимальне та раціональне використання власних кадрових і матеріальних ресурсів для реабілітації учасників АТО/ООС із залученням ресурсів інших установ. Центр здійснює надання медико-психологічної, психіатричної та неврологічної допомоги учасникам i постраждалим внаслідок бойових в районах проведення АТО/ООС, виконує НДР за означеною тематикою. Ці наукові розробки ДУ «Інститут неврології, психіатрії та наркології» здійснює на базі власної установи та Військово-медичного клінічного центру Північного регіону, розробляє і пропонує для впровадження методи лікування та реабілітації, видає методичні рекомендації, інформаційні листи, іншу наукову видавничу продукцію, присвячену питанням діагностики, лікування та профілактики медикопсихологічних наслідків бойових дій в сучасних умовах, соціально-педагогічної та психологічної допомоги сім'ям 3 дітьми в період військових конфліктів тощо.

На базі Українського науково-дослідного інституту соціальної і судової психіатрії та наркології M03 України у співпраці 3 ДУ «Інститут отоларингології імені професора О.С. Коломійченка» створений Центр медикопсихологічної реабілітації, який є громадським об’єднанням, що діє за підтримки та під патронатом MO3 України, НАМН України та Національної експертної комісії з питань захисту суспільної моралі. Основними завданнями Центру $€$ надання консультативної психологопсихіатричної, медичної, соціальної та юридичної допомоги особам, які постраждали внаслідок надзвичайних подій, що сприяє якнайшвидшій їх медико-психологічній реабілітації та ресоціалізації в суспільстві.

Таким чином, НАМН України та підпорядкованими їй науково-дослідними установами зроблено значний внесок у надання високоспеціалізованої медичної допомоги військовослужбовцям і цивільному населенню під час АTO/OOC, а також внутрішньо переміщеним особам 3 тимчасово окупованих територій.

Досвід бойових дій в сучасному безпековому середовищі та особливості сучасних збройних конфліктів без сумніву має своє віддзеркалення на військово-медичній науці. Адже з розвитком військової справи розвивається й медична підтримка тих, хто воює, що в свою чергу потребує належного наукового супроводу. Тому потрібно не тільки враховувати набутий досвід бойових дій на сході України та кращі світові інновації у наданні медичної допомоги, але й формування нової організаційної культури в медичній службі Збройних Сил України, носієм якої $€$ персонал медичної служби, на шляху до євроатлантичної інтеграції України та набуттям взаємосумісності з силами Альянсу.

Оскільки в Збройних Силах склалась ситуація, коли очевидною $\epsilon$ необхідність технологічної модернізації та переходу на сучасні системи озброєння, що веде за собою необхідність удосконалення форм і способів застосування Збройних Сил України, їх організаційної структури та системи управління, тому науковий супровід, обгрунтовані пропозиції мають бути спрямовані на прийняття виважених рішень у сфері національної безпеки та оборони, запобігання помилкам, ціна яким неприйнятна особливо в тих випадках, коли це стосується здоров'я військовослужбовців.

Науковий супровід розвитку системи медичного забезпечення довів свою беззаперечну ефективність під час реалізації указів Президента України «Про рішення Ради національної безпеки і оборони України від 20 травня 2016 року «Про Стратегічний оборонний 
бюлетень України» та Державної програми розвитку Збройних Сил України на період до 2020 року, Воєнно-медичної доктрини України" [14].

Враховуючи зазначене, можна сформувати три основні напрями розвитку вітчизняної військово-медичної науки: організаційний, лікувально-профілактичний та логістичнотехнологічний.

Перший напрям полягає у розробленні та обгрунтуванні науково-методологічних основ розвитку системи медичного забезпечення Збройних Сил України, планування, організації та управління медичним забезпеченням Збройних Сил України в ситуаціях їх застосування (організаційних заходів щодо збереження та зміцнення здоров'я особового складу, запобігання виникненню i розповсюдженню хвороб, надання медичної допомоги військовослужбовцям, лікування і відновлення їх працездатності та боєздатності після поранень, уражень, захворювань і травм); проведенні досліджень у сфері стандартизації медичного забезпечення та надання медичної допомоги для досягнення взаємосумісності 3 державамичленами НАTO, а також метрологічного супроводу застосування сучасних методів вимірювання та засобів вимірювальної техніки, випробувань і контролю в галузі військової медицини.

Другий напрям це розроблення науково обгрунтованих заходів превентивної медицини з урахуванням епідеміологічних досліджень інфекційної та неінфекційної захворюваності, смертності, професійної дискваліфікації військовослужбовців, спрямованих на запобігання захворюванням, їхньому розвитку та на зміцнення здоров'я військовослужбовців; проведення досліджень з визначення комплексу заходів щодо забезпечення епідемічного благополуччя у Збройних Силах України шляхом розроблення науково-методичних засад

\section{Висновки}

1. НАМН України та підпорядковані їй науково-дослідні установи, в структурі яких $\epsilon$ клінічні підрозділи, під час АТО/ООС взяли активну участь у наданні медичної допомоги пораненим, ураженим, травмованим і хворим військовослужбовцям ЗС України та інших військових формувань.

2. Робота НАМН України щодо надання медичної допомоги пораненим, ураженим, травмованим і хворим військовослужбовцям ЗС України та інших військових формувань була багатовекторною і велася за такими основними напрямами: організації та проведення санітарно-гігієнічних і протиепідемічних заходів у Збройних Силах України; розроблення та наукового обгрунтування сучасних ефективних медичних технологій надання медичної допомоги, лікування та реабілітації відповідно до стандартів медичної допомоги, клінічних протоколів та інших галузевих стандартів у сфері охорони здоров'я, а також військово-медичних стандартів; здійснення науково-методичного супроводу заходів професійного психофізіологічного відбору, супроводу професійної діяльності та відновлення працездатності (психофізіологічної підготовки) військових фахівців

Третій напрям полягає у проведенні досліджень з обгрунтування потреби Медичних сил Збройних Сил України в медичній техніці та майні, розроблення нормативів та порядку медичного постачання; здійсненні наукового супроводу д розвитку медичних інформаційних систем та технологій, а також інформаційноаналітичного забезпечення медичної звітності та медичної статистики в Збройних Силах України; проведенні досліджень 3 визначення та наукового обгрунтування медико-технічних вимог до медичної техніки, а також здійсненні наукового супроводу їх розроблення та дослідної експлуатації.

I на кінець, подальший розвиток системи медичного забезпечення інших складових сил оборони потребуватиме наукового супроводу щодо визначення ефективних заходів інтеграції системи медичного забезпечення військ 3 системою цивільної охорони здоров'я на засадах єдиного медичного простору, а також спільних досліджень з Національною академією медичних наук України в інтересах розвитку системи медичного забезпечення Збройних Сил України здійсненні обміну досвідом 3 міжнародними установами та організаціями з питань військовомедичної науки.

участь в організаційно-методичному керівництві організацією надання медичної допомоги військовослужбовцям;

надання високотехнологічної високоспеціалізованої медичної допомоги найбільш тяжким пораненим, ураженим, травмованим і хворим військовослужбовцям, потребуючим довготривалого та складного лікування;

збір, аналіз та узагальнення набутого досвіду медичного забезпечення військ під час бойових дій в районах проведення АТО/ООС, а також пошук і наукове обгрунтування сучасних підходів до діагностики та розроблення нових методик 
надання медичної допомоги пораненим, ураженим, травмованим i хворим військовослужбовцям - учасникам бойових дій.

3. Під час АТО/OОС клінічні установи НАМН України не припиняли надання високоспеціалізованої медичної допомоги цивільному населенню України, зокрема й вимушеним переселенцям 3 тимчасово окупованих територій.

4. Провідними вченими та практиками науково-дослідних установ НАМН України, Української ВМА, військово-медичних клінічних центрів МО України та вищих навчальних закладів М03 України під загальним керівництвом та координацією відділу військово-медичної науки при Президії НАМН України проведено та надалі проводяться наукові дослідження щодо узагальнення досвіду

\section{Література}

1. Шоста річниця початку АТО: цифри і факти / [Електронний ресурс]. - Знято 03.08.2020. - Режим доступу: www.slovoidilo.ua / shosta-richnycya-pochatkuato-cyfry-fakty.

2. Наказ Генерального штабу Збройних Сил України від 20.12.2017 року № 445 «Про затвердження Доктрини медичного забезпечення Збройних Сил України».

3. Наказ Генерального штабу Збройних Сил України від 11.02.2019 року № 60 «Про затвердження Настанови 3 медичного забезпечення Збройних Сил України на особливий період».

4. Розпорядження Кабінету Міністрів України від 24 травня 2017 року № 352-р «Деякі питання медичного забезпечення військовослужбовців, осіб рядового i начальницького складу та поліцейських, які беруть участь в антитерористичній операції та здійсненні заходів із забезпечення національної безпеки i оборони, відсічі і стримування збройної агресії Російської Федерації у Донецькій та Луганській областях».

5. Наказ Міністерства оборони України та Міністерства охорони здоров'я України від 7.02.2018 року № 49/180 «Про визначення механізму надання вторинної (спеціалізованої) і третинної (високоспеціалізованої) медичної допомоги військовослужбовцям, які беруть участь в антитерористичній операції та здійсненні заходів із забезпечення національної безпеки і оборони, відсічі і стримування збройної агресії Російської Федерації та/або в умовах запровадження воєнного чи надзвичайного стану» (зі змінами). Зареєстрований у Міністерстві юстиції України 28.02.2018 року за № 252/31704.

6. Жаховський В.О., Лівінський В.Г. Методичні рекомендації з організації роботи цивільних закладів охорони здоров'я щодо надання вторинної (спеціалізованої) та третинної (високоспеціалізованої) медичної допомоги військовослужбовцям Збройних медичного забезпечення 3С України та інших військових формувань під час АТО/ООС та пошуку нових ефективних технологій діагностики, лікування та реабілітації поранених, уражених, травмованих і хворих військовослужбовців, а також цивільного населення в районах проведення АТО/ООС.

5. Завдяки злагодженій діяльності НАМН України та підпорядкованих їй науководослідних установ зроблено вагомий внесок у надання високоспеціалізованої медичної допомоги та лікування поранених, уражених травмованих і хворих військовослужбовців, а також сформовано основні напрями розвитку вітчизняної військово-медичної науки: організаційний, лікувально-профілактичний та логістично-технологічний.

Сил України та інших військових формувань // Методичні рекомендації. Київ: «Видавництво Людмила», 2019.137 с.

7. Жаховський В.О., Лівінський В.Г. Єдиний медичний простір та військова медицина // Монографія. ISBN 978-617-7638-00-0 / Київ: «Видавництво Людмила». - 2018. - 336 с.

8. Закон України «Основи законодавства України про охорону здоров’я» від 19.11.1992 року № 2801-XII / Відомості Верховної Ради України (ВВР), 1993, № 4, ст. 19.

9. Статут Національної академії медичних наук України, затверджений Загальними зборами Національної академії медичних наук України 5 квітня 2016 року та зареєстрований Міністерством юстиції України (наказ від 27 липня 2016 року № 2333/5).

10. Рішення Комітету Верховної Ради України 3 питань охорони здоров'я від 4.09.2014 року № 04-26/438 «Про вжиття невідкладних заходів для поліпшення стану організації медичного забезпечення населення та учасників антитерористичної операції».

11. Указ Президента України від 14 листопада 2014 року № 880/2014 «Про рішення Ради національної безпеки і оборони України від 4 листопада 2014 року «Про невідкладні заходи із забезпечення державної безпеки».

12. Наказ Національної академії медичних наук України від 19 листопада 2014 року № 18 «Про невідкладні заходи щодо надання медичної допомоги установами НАМН України»

13. Наказ Міністерства охорони здоров'я України від 18 лютого 2015 року № 75 «Про додаткові заходи щодо забезпечення функціонування закладів охорони здоров'я в умовах особливого періоду та подолання наслідків надзвичайної ситуації державного рівня соціального та воєнного характеру».

14. Постанова Кабінету Міністрів України від 31 жовтня 2018 року № 910 «Про затвердження Воєнномедичної доктрини України». 


\section{References}

1. The sixth anniversary of the beginning of the antiterrorist operation: figures and facts / [Electronic resource]. - Retrived on 03.08.2020. - Access mode: https://www.slovoidilo.ua/2020/04/14/infografika/bezpeka/shosta-richnycya-pochatku-ato-cyfry-fakty.

2. Order of the General Staff of the Armed Forces of Ukraine dated 20.12.2017 № 445 «On approval of the Doctrine of medical support of the Armed Forces of Ukraine».

3. Order of the General Staff of the Armed Forces of Ukraine dated 11.02.2019 № 60 «On approval of the Instruction on medical support of the Armed Forces of Ukraine for a special period».

4. Order of the Cabinet of Ministers of Ukraine of May 24, 2017 № 352-r «Some issues of medical care for servicemen, privates and police officers involved in the anti-terrorist operation and the implementation of measures to ensure national security and defense, repulse and deter armed aggression of the Russian Federation in Donetsk and Luhansk regions» - Retrived on 03.08.2020. Access mode: https://zakon.rada.gov.ua/laws/show/3522017-p\#Text

5. Order of the Ministry of Defense of Ukraine and the Ministry of Health of Ukraine dated February 7, 2018 № $49 / 180$ "On determining the mechanism of providing secondary (specialized) and tertiary (highly specialized) medical care to servicemen participating in the antiterrorist operation and implementation of measures to ensuring national security and defense, repelling and deterring armed aggression by the Russian Federation and / or in the context of a martial law or state of emergency "(as amended). Registered in the Ministry of Justice of Ukraine on February 28, 2018 for № 252/31704. Retrived on 03.08.2020. - Access mode: https://zakon.rada.gov.ua/laws/show

\section{zz0252-18\#Text}

6. Zhakhovsky, V.O., Livinsky, V.G. (2019). Methodical recommendations on the organization of work of civilian health care institutions on the provision of secondary (specialized) and tertiary (highly specialized) medical care to servicemen of the Armed Forces of Ukraine and other military formations: Methodical recommendations. Kyiv: Lyudmila Publishing House, $137 \mathrm{p}$.

7. Zhakhovsky, V.O., Livinsky, V.G. (2018). Unified medical space and military medicine. Monograph. Kyiv:
Lyudmila Publishing House. 336 p. ISBN 978-617-763800-0

8. Law of Ukraine «Fundamentals of the legislation of Ukraine on health care»(1993) № 2801-XII Information of the Verkhovna Rada of Ukraine (VVR), № 4, Art. 19. Retrived on 03.08.2020. - Access mode: https://zakon.rada.gov.ua/laws/show/2801-12\#Text

9. Charter of the National Academy of Medical Sciences of Ukraine, approved by the General Meeting of the National Academy of Medical Sciences of Ukraine on April 5, 2016 and registered by the Ministry of Justice of Ukraine (order of July 27, 2016 № 2333/5). - Retrived on 03.08.2020. Access mode: http://amnu.gov.ua/statut-namn-ukrayiny/

10. Decision of the Committee of the Verkhovna Rada of Ukraine on Health Care dated 4.09.2014 № 04-26 / 4-38 «On taking urgent measures to improve the organization of medical care for the population and participants in the antiterrorist operation.» Records of the MMD of Ministry of Defense of Ukraine. Ref. 3. V. 4. 297-298.

11. Decree of the President of Ukraine of November 14, 2014 № 880/2014 «On the decision of the National Security and Defense Council of Ukraine of November 4, 2014» On urgent measures to ensure state security». Retrived on 03.08.2020. - Access mode: https://zakon.rada.gov.ua/laws/show/n001452514\#Text

12. Order of the National Academy of Medical Sciences of Ukraine of November 19, 2014 № 18 «On urgent measures to provide medical care by the institutions of the National Academy of Medical Sciences of Ukraine» Retrived on 03.08.2019. - Access mode: http://amnu.gov.ua/zagolovok-251/

13. Order of the Ministry of Health of Ukraine «On additional measures to ensure the functioning of health care facilities in a special period and overcoming the consequences of the state of emergency of the state level of social and military nature», February 18, 2015 № 75. Retrived on 03.08.2019. - Access mode: https://zakon.rada.gov.ua /rada/show/v0075282-15\#Text

14. Resolution of the Cabinet of Ministers of Ukraine «On approval of the Military Medical Doctrine of Ukraine», October 31, 2018 № 910. Retrived on 03.08.2020. - Access mode: https://zakon.rada.gov.ua/laws/show/910-2018$\underline{\text { п\#Text }}$

\title{
РОЛЬ И МЕСТО НАЦИОНАЛЬНОЙ АКАДЕМИИ МЕДИЦИНСКИХ НАУК УКРАИНЫ В ПРЕДОСТАВЛЕНИИ МЕДИЦИНСКОЙ ПОМОЩИ ВОЕННОСЛУЖАЩИМ ВО ВРЕМЯ АТО / ООС
}

\author{
В.И. Цымбалюк ${ }^{1}$, И.А. Лурин ${ }^{1}$, В.А. Жаховский ${ }^{2}$, В.Г. Ливинский ${ }^{2}$, А.В. Швец ${ }^{2}$ \\ ${ }^{1}$ Национальная академия медицинских наук Украины, г. Киев, Украина. \\ 2 Украинская военно-медищинская академия, г. Киев, Украина.
}

Цель работы - исследование места и роли Национальной академии медицинских наук (НАМН) Украины и подчиненных ей научно-исследовательских учреждений, в структуре которых имеются клинические подразделения, в системе оказания медицинской помощи раненым, пораженным, травмированным и больным военнослужащим во время антитеррористической операции и операции Объединенных сил (АТО / ООС). 
Материалы и методы. Использованы нормативно-правовые акты по вопросам национальной безопасности государства и охраны здоровья в Украине, публикации в открытых научных источниках о деятельности Национальной академии медицинских наук Украины в целях оказания медицинской помощи военнослужащим во время АТО / ООС. Методы исследования - библиографический, статистический, аналитический, системного подхода.

Результаты. НАМН Украины и подчиненные ей научно-исследовательские учреждения, в структуре которых имеются клинические подразделения, во время АТО / ООС приняли активное участие в оказании медицинской помощи раненым, пораженным, травмированным и больным военнослужащим ВС Украины и других военных формирований. Работа НАМН Украины по предоставлению медицинской помощи военнослужащим была многовекторной и велась по нескольким направлениям: организационный, непосредственного оказания медицинской помощи и научного сопровождения. Клинические учреждения НАМН Украины во время АТО / ООС не прекращали оказания высокоспециализированной медицинской помощи гражданскому населению Украины, в том числе и вынужденным переселенцам из районов проведения АТО / ООС.

Выводы. Благодаря слаженной деятельности Президиума АМН Украины и подчиненных ей научноисследовательских учреждений сделан весомый вклад в оказание высокоспециализированной медицинской помощи раненым, пораженным травмированным и больным военнослужащим во время АТО / ООС, а также сформированы основные направления развития отечественной военно-медицинской науки: организационный, лечебно профилактический и логистически-технологический.

ключевые слова: здравоохранение, медицинская помощь, НАМН Украины.

\title{
THE ROLE AND PLACE OF THE NATIONAL ACADEMY OF MEDICAL SCIENCES OF UKRAINE IN PROVIDING MEDICAL CARE TO SERVICEMEN DURING ATO / JFO
}

\author{
V.I. Tsymbalyuk ${ }^{1}$, I.A. Lurin ${ }^{1}$, V.0. Zhakhovsky ${ }^{2}$, V.G. Livinskyi ${ }^{2}$, A.V. Shvets ${ }^{2}$ \\ ${ }^{1}$ National Academy of Medical Sciences of Ukraine, Kyiv, Ukraine \\ ${ }^{2}$ Ukrainian Military Medical Academy, Kyiv, Ukraine
}

The purpose of the work is to study the place and role of the National Academy of Medical Sciences (NAMS) of Ukraine and its subordinate research institutions, which include clinical units, in the system of medical care for wounded, injured, traumatized and sick servicemen during the anti-terrorist operation and Joint Forces operation (ATO / JFO).

Materials and methods. It was used legal acts on national security and health in Ukraine, publications in open scientific sources on the activities of the National Academy of Medical Sciences of Ukraine to provide medical care. Methods - bibliographic, statistical, analytical, system's analisys.

Results. NAMS of Ukraine and its subordinate research institutions, in the structure of which there are clinical units, during the ATO / JFO took an active part in providing medical care to wounded, injured, injured and sick servicemen of the Armed Forces of Ukraine and other military formations. The work of the National Academy of Medical Sciences of Ukraine on providing medical care to servicemen was multi-vector and was conducted in several areas: organizational, direct medical care and scientific support. During the anti-terrorist operation / Joint Forces operation, the clinical institutions of the National Academy of Medical Sciences of Ukraine did not stop providing highly specialized medical care to the civilian population of Ukraine, including IDPs from the areas of anti-terrorist operation / Joint Forces operation.

Conclusions. Thanks to the coordinated activities of the Presidium of the National Academy of Medical Sciences of Ukraine and its subordinate research institutions, a significant contribution was made to the provision of highly specialized medical care to wounded, injured and sick servicemen during the ATO / JFO.

Keywords: health care, medical care, NAMS of Ukraine.

Конфлікт інтересів: відсутній.

Conflicts of interest: authors have no conflict of interest to declare.

\section{Відомості про авторів:}

Цимбалюк B.I. А,B,C,E,F - д.мед.н., професор, Президент Національної академії медичних наук України, академік НАМН України, член-кореспондент Національної академії наук України, https://orcid.org/0000-0001-7544-6603; вул. Герцена, 12, м. Київ, 04050, Україна.

Лурін І.А. А,В,C,E,F - д.мед.н., професор, керівник відділу військово-медичної науки при Президії НАМН України, член-кореспондент НАМН України, https://orcid.org/0000-0001-6280-1725; вул. Герцена, 12, м. Київ, 04050, Україна. 
Жаховський В.О. В,C,D,E - к.н.держ.упр., доц., провідний науковий співробітник Науково-дослідного інституту проблем військової медицини Української військово-медичної академії; https://orcid.org/00000002-2665-2766, Email: zhahovskiy-viktor@ukr.net, вул. Московська, 45/1, м. Київ, 01015, Україна.

Лівінський В.Г. В,C,D,E - к.мед.н., провідний науковий співробітник Науково-дослідного інституту проблем військової медицини Української військово-медичної академії; https://orcid.org/0000-00021102-1128, Email: v.livinskiy@gmail.com, вул. Московська, 45/1, м. Київ, 01015, Україна.

Швець А.В. В,C,D,E - полковник медичної служби, д.мед.н., с.н.с., заступник начальника академії з наукової роботиУкраїнської військово-медичної академії; https://orcid.org/0000-0002-9461-7129, вул. Московська, 45/1, м. Київ, 01015, Україна.

$A$ - концепція та дизайн дослідження; $B$ - збір даних; $C$ - аналіз та інтерпретація даних;

$D$ - написання статmi; $E$ - редагування статmi; F- остаточне затвердження статті.

\section{Сведения об авторах:}

Цимбалюк В.И. - д.мед.н., профессор, Президент Национальной академии медицинских наук Украины, академик НАМН Украины, член-корреспондент Национальной академии наук Украины, Киев.

Лурин И.А. - д.мед.н., профессор, руководитель отдела военно-медицинской науки при Президиуме НАМН Украины, член-корреспондент НАМН Украины, г. Киев.

Жаховский В.A. - к.н. держ. упр., доц., ведущий научный сотрудник Научно-исследовательского института проблем военной медицины Украинской военно-медицинской академии, г. Киев.

Ливинский В.Г. - к.мед.н., ведущий научный сотрудник Научно-исследовательского института проблем военной медицины Украинской военно-медицинской академии, г. Киев.

Швец А. В., полковник медицинской службы, д-р мед. наук, старший научный сотрудник, заместитель начальника Украинской военно-медицинской академии по научной работе, г. Киев.

\section{Information about authors:}

Tsimbalyuk V.I. A,B,C,E,F - MD, PhD, DSc, Professor, President of the National Academy of Medical Sciences of Ukraine, Academician of the National Academy of Medical Sciences of Ukraine, Corresponding Member of the National Academy of Sciences of Ukraine, https://orcid.org/0000-0001-7544-6603; Herzen street, 12, Kyiv, 04050, Ukraine.

Lurin I.A. A,B,C,E,F - MD, PhD, DSc, Professor, Head of the Department of Military Medical Science at the Presidium of the National Academy of Medical Sciences of Ukraine, Corresponding Member of the National Academy of Medical Sciences of Ukraine, Major General of the Medical Service, https://orcid.org/0000-00016280-1725; Herzen street, 12, Kyiv, 04050, Ukraine.

Zhakhovsky V.O. B,C,D,E - candidate of science in public administration, associate professor, Research Institute of Military Medicine of the Ukrainian Military Medical Academy, leading researcher of research department of medical support organization, Email: zhahovskiy-viktor@ukr.net, https://orcid.org/0000-00022665-2766, Kyiv

Livinskyi V.G. B,C,D,E,- candidate of medical sciences, Research Institute of Military Medicine of the Ukrainian Military Medical Academy, leading researcher of the research department of medical standardization and metrological support, Email: v.livinskiy@gmail.com, https://orcid.org/0000-0002-1102-1128, Kyiv

Shvets A. V. B,C,D,E - Col. MS, MD, PhD, DSc, Senior Researcher, Deputy chief of Ukrainian Military Medical Academy for sciense, Kyiv, E-mail: shvetsandro@gmail.com, https://orcid.org/0000-0002-9461-7129.

$A$ - research concept and design; $B$ - collection and/or assembly of data; $C$ - data analysis and interpretation; $D$ - writing the article; $E$ - critical revision of the article; $F$ - final approval of the article. 